\title{
Physicochemical Quality of Water from Chuho Springs, Kisoro District, Uganda
}

Gerald Nkurunziza $^{\mathrm{a}}$, Timothy Omara ${ }^{\mathrm{b}, \mathrm{c}, \mathrm{d}}$, Caroline Kiwanuka Nakigulia, ${ }^{\mathrm{a}, \mathrm{c}}$, Paul Mukasa ${ }^{\mathrm{a}}$, Denis Byamugisha $^{\mathrm{a}}$, Emmanuel Ntambi $^{\mathrm{a}}$

a Department of Chemistry, Faculty of Science, Mbarara University of Science and Technology, P.O. Box 1410, Mbarara, Uganda.

${ }^{\mathrm{b}}$ Department of Chemistry and Biochemistry, School of Sciences and Aerospace Studies, Moi University, Uasin Gishu County, P.O. Box 3900, Eldoret, Kenya.

${ }^{\mathrm{c}}$ Africa Center of Excellence II in Phytochemicals, Textiles and Renewable Energy (ACE II PTRE), Moi University, Uasin Gishu County, P.O. Box 3900, Eldoret, Kenya.

d Department of Quality Control and Quality Assurance, AgroWays Uganda Limited, Plot 34-60, Kyabazinga Way, P.O. Box 1924, Jinja, Uganda.

\section{emmantambi@must.ac.ug}

Keywords: $p H$, temperature, conductivity, trace metals, water quality index.

In the current study, water from Chuho springs used as the main water source in Kisoro municipality, Uganda were assessed for their suitability as drinking water. The temperature, turbidity, conductivity, total dissolved solids, dissolved oxygen, biological oxygen demand, total hardness, total alkalinity, calcium, magnesium, phosphates, iron, copper, arsenic, chlorides and the fluoride content of the water samples were determined. Not all the parameters met World Health Organizations' guidelines for drinking water. Temperature, dissolved oxygen and fluorides were outside the recommended limits of $15{ }^{\circ} \mathrm{C}, 10-12 \mathrm{mg} / \mathrm{L}$ and $1.5 \mathrm{mg} / \mathrm{L}$, respectively. Further studies should assess the microbiological and sanitary profile of the springs.

\section{Introduction}

Access to clean, reliable, affordable and safe water is a challenge to at least 1.1 million people globally $[1,2]$. A recent report articulated by the United Nations World Water Development indicates that close to four billion people (twothirds of the global population) experiences severe water scarcity for at least a month every year [3]. Up to two billion of the four billion subsists on water from sources that are contaminated with faeces, which have the potential to expand the transmission window of water-borne diseases such hepatitis A, dysentery, typhoid, diarrhoea and cholera $[4,5]$. Consumption of contaminated drinking water accounts for at least 485,000 annual diarrhoeal deaths $[6,7]$.

Projections hold it that by 2025 , half of the global population will be in water-stressed areas and this is emphatic of the need to monitor the 
physicochemical and microbiological quality of water sources. Water is at the core of sustainable development, and is an inevitable fuel for economic development $[5,6]$. The major barriers to addressing water challenges in developing nations range from chronic poverty to poor governance, land use dynamics and the effects of the decadal climate change [8]. Thus, the Sustainable Development Goal target 6.1 calls for universal and equitable access to safe and affordable drinking water [6].

Sub-Saharan Africa, and Eastern Africa in particular are two of the regions of the world with limited access to clean and safe water $[9,10]$. Uganda is one of the most hit countries in the Sub-Sahara with water scarcity problem [11]. A recent print indicated that more than 21 million ( $51 \%$ of) Ugandans do not have access to safe drinking water [12]. In tandem with the sanitation crisis, both the physicochemical and microbiological profiles of water in some areas in Uganda have been indicated to be unfit for drinking and other purposes [13-22].

Previous reports raised concerns over the reduced levels and possible contamination of Chuho springs by anthropogenic activities [2325]. Yet in Kisoro district of Uganda, only $44 \%$ of the population have access to safe water $(43 \%$ rural and 57\% urban), with only two pumped water schemes fed by Chuho catchment [26]. Thus, dysentery, cholera and other water-borne disease outbreaks have been recurrent in the district [27]. As a contribution to water quality monitoring and public health, this study for the first time aimed at assessing the physicochemical quality of water from Chuho springs used in Kisoro district of Western Uganda and the health implications.

\section{Experimental part}

\section{Description of the study area}

The water samples analyzed in this study were taken from Chuho springs, Kisoro district, Uganda $\left(1.2209^{\circ} \mathrm{S}\right.$ and $29.6499^{\circ} \mathrm{E}$; Figure 1). Kisoro district share common frontiers with Kanungu district in the North, Kabale district to the East, Rwanda to the South and the Democratic Republic of the Congo to the West. The district population stood at 281,705 as of 2014 [28], 65\% of which uses piped water from National Water and Sewerage Cooperation and the rest uses water from other sources. The total area of the district is $701.4 \mathrm{~km}^{2}, 78 \%$ of it being dedicated to agriculture while $8 \%$ is covered by water. The rest of the land comprises towns and factories, notably tea processing industries. Kisoro has a population density of 362.6 per $\mathrm{km}^{2}$ and the growth rate is nearly $5 \%$ per year. The main economic activities include farming, trade and fishing especially in Lake Mutanda, Lake Kayumbu and Lake Chahafi.

Chuho water has six springlets with identical hydrogeochemistry and deliver water to a basin-like depression from where a small river flows northwards towards Lake Mutanda [23, 
29]. Chuho water is located at an elevation of 1,829 meters above sea level, about four kilometers north of Kisoro town. The springs are recharged by Kigezi wetland but the Chuho watershed catchment has been indicated to be affected by land degradation, impacting the water supply available to downstream users [23].

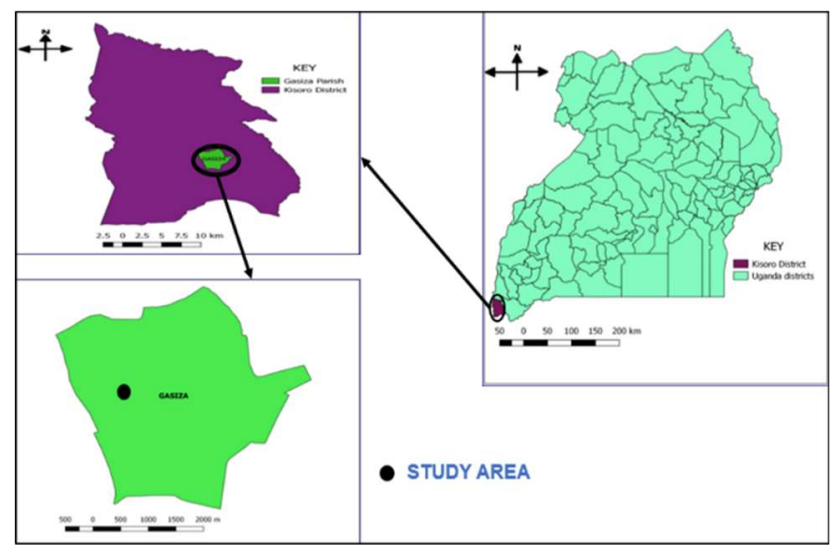

Figure 1. Map of Uganda showing the location of Chuho springs in Kisoro district.

\section{Sample collection and analysis}

A total of 30 samples were collected from four Chuho springs (A, B, C and D) and a commonly used tap water between January 2019 and February 2019. The samples were collected between 9:00 am to 10:00 am (East African Standard Time) as described by Omara et al. [15]. Non-conservable parameters such as $\mathrm{pH}$, temperature, conductivity and total dissolved solids were determined on-site using a hand held Jenway 370 pH/temperature meter (Jenway Gransmore Green, England) and Jenway 4520 Conductivity/TDS meter (Keison Products, England) [15, 30]. All the samples were transported in an icebox and the remaining parameters were analyzed within 12 hours of collection at the Chemistry Laboratory of Mbarara University of Science and Technology, Mbarara (Uganda) following the standard method for examination of water and wastewater [31].

\section{Data analysis}

Data were presented as means \pm standard deviation of triplicates. The means were compared with World Health Organization (WHO) guidelines for drinking water [32]. Oneway ANOVA was used to separate the means, while Pearson's bivariate correlation was used to establish the relationship between the parameters. Analyses were performed at $\mathrm{p}<0.05$ using SPSS statistical software (Version 20, IBM Inc.).

The water quality index (WQI) was calculated according to The Canadian Council of Ministers of the Environment Water Quality Index (CCME-WQI) [33] using equation 1.

$$
\mathrm{CCME}-\mathrm{WQI}=100-\left(\frac{\sqrt{\mathbf{F 1}^{2}+\mathbf{F}^{2}+\mathbf{F} \mathbf{3}^{3}}}{\mathbf{1 . 7 3 2}}\right)
$$

Where $F 1, F 2$ and $F 3$ is the water quality parameters (objectives) of scope (percentage of individual variables that do not meet objectives), frequency (percentage of individual tests that do not meet objectives) and amplitude (amount by which failed tests do not meet their objectives), respectively. 


\section{Results and Discussion}

The analytical results of the analysis of physicochemical parameters of the water samples are given in Table 1.

\section{Temperature}

Temperature is one of the most essential parameters used to evaluate the quality of drinking water. It affects many phenomena including the rate of chemical reactions in water, reduction in solubility of gases and amplification of taste and colour $[34,35]$. The temperatures obtained in this study ranged from 20.85 to 21.10 ${ }^{\circ} \mathrm{C}$. There were no significant differences in the temperature of water from the springs $(p=$ 0.527). All the recorded water temperatures were above the WHO recommended level of $15^{\circ} \mathrm{C}$ [32]. The results of the current study are in congruence with previous studies. Haruna et al. [20] reported temperatures of $24.3 \pm 0.5$ to 25.0 $\pm 0.8{ }^{\circ} \mathrm{C}$ for Katwe and Kisenyi springs of Kampala city which are comparable to the values recorded in this study. In Kampala (Natete) and Lira district (Uganda), Okot and Otim [36] reported temperatures of $23.00-25.50{ }^{\circ} \mathrm{C}$ for spring water. In Mbarara district of Uganda, Lukubye and Andama [19] reported temperatures of $22.38 \pm 0.16{ }^{\circ} \mathrm{C}$ and $23.45 \pm 0.23{ }^{\circ} \mathrm{C}$ for springs in Kiswahili and Kisenyi. Similarly, Omara et al. [15] reported that Katalina, Airport 1 and Airport 2 spring water in Kyambogo University propinquity had mean temperatures of $20.53 \pm 1.23,21.53 \pm 0.60$ and $20.33 \pm 1.62{ }^{\circ} \mathrm{C}$, respectively. These temperatures were not statistically different, and were lower than $23.1^{\circ} \mathrm{C}$ to $28.8^{\circ} \mathrm{C}$ recorded earlier in the dry season of 2013 for Katalina, Katoogo and Bukuuku springs in Kampala and its environs [14]. The variations in temperature of the samples may be attributed to sampling locations as some of the samples were collected from the underground while others were partly on the surface exposed to direct sunlight, richness in organic matter (hence microbial activities) and the generally higher temperatures in Uganda during January. It is desirable to have water temperatures not exceeding $15^{\circ} \mathrm{C}$ as the palatability of water is enhanced by its coolness [37].

\section{Colour}

Colour is primarily a water quality concern for aesthetic reasons. Coloured (turbid) water is translated as being unfit to drink, even though it may be safe. Colour may also indicate the presence of organic substances, such as algae or humic compounds, an aspect which has been employed in the assessment of water quality. Colour values of water samples in this study ranged from $6.38 \pm 0.92$ to $9.28 \pm 1.84$ colour units (CU) which were within the WHO permissible limit of $15.0 \mathrm{CU}$ [32]. There were no significant differences in the colour of the spring and tap water samples $(\mathrm{p}=0.667)$. Previous studies in Uganda examined the turbidity levels of spring water rather than colour. Okot and Otim [36], Haruna et al. [20] and Omara et al. [15] reported that the turbidity of springs in Lira and 
FRENCH-UKRAINIAN JOURNAL OF CHEMISTRY (2021, VOLUME 09, ISSUE 02)

Table 1. Physicochemical profile of water from some water sources used in Kisoro municipality, Western Uganda.

\begin{tabular}{|c|c|c|c|c|c|c|c|c|}
\hline Parameter & Spring A & Spring B & Spring C & Spring D & Tap water & p-value & Range & WHO guidelines \\
\hline Temperature $\left({ }^{\circ} \mathrm{C}\right)$ & $22.07 \pm 0.87$ & $21.98 \pm 0.74$ & $22.10 \pm 0.55$ & $20.85 \pm 0.53$ & $21.10 \pm 0.54$ & 0.527 & $20.85-22.10$ & 15.00 \\
\hline Colour (colour units) & $8.80 \pm 0.94$ & $9.28 \pm 1.84$ & $6.77 \pm 0.79$ & $6.90 \pm 2.70$ & $6.38 \pm 0.92$ & 0.621 & $6.38-9.28$ & 15.0 \\
\hline $\mathrm{pH}$ & 7.76 & 7.73 & 8.07 & 8.40 & 8.25 & 0.000 & $7.73-8.40$ & $6.5-8.5$ \\
\hline Dissolved oxygen $(\mathrm{mg} / \mathrm{L})$ & $4.14 \pm 0.87$ & $4.87 \pm 0.59$ & $3.06 \pm 0.32$ & $3.15 \pm 0.27$ & $2.41 \pm 0.15$ & 0.019 & $2.14-4.87$ & $10-12$ \\
\hline Biochemical oxygen demand $(\mathrm{mg} / \mathrm{L})$ & $1.54 \pm 0.36$ & $2.03 \pm 0.25$ & $2.46 \pm 0.56$ & $1.31 \pm 0.15$ & $1.36 \pm 0.17$ & 0.098 & $1.31-2.46$ & 50 \\
\hline Total dissolved solids $(\mathrm{mg} / \mathrm{L})$ & $366.07 \pm 4.35$ & $394.83 \pm 2.31$ & $400.7 \pm 0.50$ & $460.32 \pm 1.08$ & $64.49 \pm 0.56$ & 0.000 & $64.49-460.32$ & $500-1500$ \\
\hline Electrical conductivity $(\mu \mathrm{S} / \mathrm{cm})$ & $448.28 \pm 1.29$ & $455.47 \pm 2.72$ & $453.32 \pm 3.67$ & $425.33 \pm 3.90$ & $105.49 \pm 0.68$ & 0.000 & $105.49-455.47$ & $750-1000$ \\
\hline Total alkalinity $(\mathrm{mg} / \mathrm{L})$ & $\begin{array}{l}131.465 \pm \\
15.41\end{array}$ & $\begin{array}{l}165.16 \pm \\
33.56\end{array}$ & \begin{tabular}{|l|}
$146.44 \pm$ \\
25.78
\end{tabular} & $\begin{array}{l}146.81 \pm \\
26.58\end{array}$ & $\begin{array}{l}120.01 \pm \\
13.03\end{array}$ & 0.732 & $120.01-165.16$ & 200 \\
\hline Total hardness $(\mathrm{mg} / \mathrm{L})$ & $70.42 \pm 2.91$ & $71.20 \pm 2.85$ & $68.00 \pm 1.55$ & $70.98 \pm 1.62$ & $33.66 \pm 2.08$ & 0.000 & $33.66-71.20$ & $100-300$ \\
\hline Magnesium (mg/L) & $60.34 \pm 3.08$ & $60.54 \pm 2.77$ & $55.66 \pm 1.52$ & $54.52 \pm 2.75$ & $20.17 \pm 2.53$ & 0.000 & $20.17-60.54$ & $30-50$ \\
\hline Calcium (mg/L) & $10.08 \pm 0.93$ & $10.66 \pm 0.89$ & $12.33 \pm 0.56$ & $16.47 \pm 2.17$ & $13.49 \pm 1.14$ & 0.012 & $10.08-16.47$ & $50-75$ \\
\hline Fluoride $(\mathrm{mg} / \mathrm{L})$ & $2.15 \pm 0.06$ & $2.45 \pm 0.10$ & $2.45 \pm 0.10$ & $2.27 \pm 0.16$ & $0.11 \pm 0.01$ & 0.000 & $0.11-2.45$ & 0.15 \\
\hline Chloride (mg/L) & $22.64 \pm 1.15$ & $20.35 \pm 1.37$ & $21.41 \pm 2.89$ & $20.69 \pm 2.26$ & $30.04 \pm 6.65$ & 0.288 & $20.35-30.04$ & 250 \\
\hline Phosphates $(\mathrm{mg} / \mathrm{L})$ & $0.75 \pm 0.07$ & $0.89 \pm 0.05$ & $0.89 \pm 0.04$ & $0.81 \pm 0.07$ & $0.17 \pm 0.05$ & 0.000 & \begin{tabular}{|l|}
$0.17-0.89$ \\
\end{tabular} & 5 \\
\hline Copper $(\mu \mathrm{g} / \mathrm{L})$ & $9.15 \pm 2.04$ & $8.85 \pm 2.67$ & $11.17 \pm 1.11$ & $0.72 \pm 0.40$ & $6.87 \pm 3.02$ & 0.017 & $0.72-11.17$ & 2000 \\
\hline Iron $(\mathrm{mg} / \mathrm{L})$ & $0.01 \pm 0.02$ & $0.05 \pm 0.02$ & $0.09 \pm 0.02$ & $0.03 \pm 0.01$ & $0.03 \pm 0.01$ & 0.078 & $0.01-0.09$ & NL \\
\hline Arsenic $(\mu \mathrm{g} / \mathrm{L})$ & BDL & BDL & BDL & $\mathrm{BDL}$ & BDL & NA & NA & 10.0 \\
\hline
\end{tabular}

BDL: Below method detection limit, NA: Not applicable, NL: No established limit. 
Kampala districts were lower than 5 Formazin Turbidity Unit which are comparable to the lower colour units recorded in this study. The colour of water is influenced by presence of organic matter, algae or dinoflagellates and minerals especially iron, manganese and other metals occurring as natural impurities and corrosive products [38].

$$
p H
$$

$\mathrm{pH}$ is a term used universally to express the intensity of acid or alkaline condition of a solution. $\mathrm{pH}$ represents an important characteristic of water and slight variation in its level can disorganize the quality of water making it unsuitable for use. High $\mathrm{pH}$ values are known to alter the toxicity of water pollutants. For example, ammonia is more toxic in alkaline water than acidic water due to free ammonia. In this study, $\mathrm{pH}$ ranged from about neutral to slightly alkaline (7.73 to 8.4 ), which was within the WHO range of 6.5-8.5 [32]. The slightly alkaline $\mathrm{pH}$ could be because of the rocks in the area. Water may become naturally alkaline as it flows over rock, silt, sand and gravel which may contain traces of minerals such as potassium, magnesium, calcium and bicarbonates. There was a significant variation in $\mathrm{pH}$ values of the spring and tap water $(\mathrm{p}<0.05)$. Studies in springs in and around Urbanite Kampala and Lira $[15,36,39]$ reported comparable $\mathrm{pH}$ values to the ones recorded in this study. For example, springs in Kyambogo University vicinity had pH of 5.33 $\pm 0.25,6.30 \pm 0.10$ and $7.10 \pm 0.46$, with only one spring having $\mathrm{pH}$ value within the acceptable limits (6.5-8.5) for drinking water [15]. A lower $\mathrm{pH}$ value (5.14) was earlier reported for Katalina spring by Moulodi and Thorsell [14], while a lower range of 4.4 to 6.6 were reported for springs in Kasenyi and Katwe [20]. In Mbarara district, lower $\mathrm{pH}$ values of 6.17 to 7.02 were reported [19]. Slightly acidic $\mathrm{pH}$ of Ugandan springs were previously thought to be induced by carbon dioxide saturation in the ground water $[15,20,40]$. It is important to note that even within the acceptable $\mathrm{pH}$ range, slightly high $\mathrm{pH}$ causes water to have a slippery feel whereas slightly low $\mathrm{pH}$ may cause water to have a bitter or metallic taste $[15,30,41]$.

\section{Dissolved oxygen}

Dissolved oxygen refers to the level of free, non-compound oxygen present in water. The different water samples obtained from springs and the tap had mean dissolved oxygen (DO) values ranging between $2.14 \pm 0.87 \mathrm{mg} / \mathrm{L}$ to $4.87 \pm 0.59 \mathrm{mg} / \mathrm{L}$. There were significant variations in DO content both within and among samples $(p=0.019)$. These results were not acceptable when compared with the WHO standards of $10-12 \mathrm{mg} / \mathrm{L}$ for DO of fresh water [42]. The obtained results were comparable to 1.90 to $15.60 \mathrm{mg} / \mathrm{L}$ reported for springs in Mbarara district by Lukubye and Andama [19] but slightly higher than 0.33 to $1.36 \mathrm{mg} / \mathrm{L}$ earlier reported in Kampala [14]. Temperature of water influences the amount of DO with only lesser 
oxygen dissolved in warm water than cold water. Correlation analysis revealed a significant negative correlation between temperature, phosphates and DO $(r=-0.683, \mathrm{p}<0.05)$.

\section{Biological oxygen demand}

When biodegradable organic matter (including organic waste) is present in water, it provides nutrient for growth of bacteria and other microorganisms causing them to multiply and where bacterial numbers are sufficient, they cause depletion of DO in the water. The biochemical oxygen demand/biological oxygen demand (BOD) is a measure of the amount of oxygen consumed by microorganisms in breaking down the organic matter.

Biological oxygen demand is a chemical procedure for determining the amount of DO needed by aerobic organisms in a body of water to break down organic material present in a given water sample at certain temperature over a specific time period [43]. In this study, there was significant variation in BOD obtained for the samples $(p=0.093)$. The values of BOD obtained in this study ranged between $1.31 \mathrm{mg} / \mathrm{L}$ and 2.46 $\mathrm{mg} / \mathrm{L}$, which were below WHO guideline of 50 $\mathrm{mg} / \mathrm{L}$ [32]. The low levels of BOD could be due to dilution effect, high temperatures [44] and natural purification systems along Chuho water springs.

Total dissolved solids
Total dissolved solids (TDS) is a measure of the amount of dissolved inorganic and organic materials in water. It affects the taste of drinking water if the concentrations exceed $1000 \mathrm{mg} / \mathrm{L}$ [42]. The TDS readings recorded in the current study ranged from $64.49 \pm 0.56 \mathrm{mg} / \mathrm{L}$ to 460.32 $\pm 1.08 \mathrm{mg} / \mathrm{L}$, which were below the range given by WHO [32]. Statistically significant mean variations in TDS were observed among the water samples $(p<0.05)$. These were lower than 345.00 to $579.00 \mathrm{mg} / \mathrm{L}$ reported for some springs in Mbarara, Uganda [19]. Further, TDS showed a significant positive correlation with temperature $(r=0.091, \mathrm{p}=0.000)$. Generally, high TDS affects the aesthetic quality of water, interferes with washing operations and can be corrosive to plumbing fixtures [41].

\section{Electrical conductivity}

The ability of a solution to conduct electric current is governed by the migration of solutions and is dependent on the nature and numbers of ionic species in that solution. This property, termed conductivity, is a useful tool to assess the purity of water. The permissible limit of electrical conductivity is $750-1000 \mu \mathrm{S} / \mathrm{cm}$ [32]. Electrical conductivity of the collected samples ranged from $105.49 \pm 0.68 \mu \mathrm{S} / \mathrm{cm}$ to $455.47 \pm 2.72 \mu \mathrm{S} / \mathrm{cm}$, which were within the permissible limit and comparable to 95-705 $\mu \mathrm{S} / \mathrm{cm}$ in Kisenyi and Katwe [20], 28-760 $\mu \mathrm{S} / \mathrm{cm}$ in Kampala and Lira [36], 158-201 $\mu \mathrm{S} / \mathrm{cm}$ in Kyambogo [15] and 685.00-715.00 $\mu \mathrm{S} / \mathrm{cm}$ for Kiswahili spring water in Mbarara, Uganda [19]. 
Moulodi and Thorsell [14] recorded and BOD. This could be because during conductivities of $155-821 \mu \mathrm{S} / \mathrm{cm}$ for Katalina, respiration oxygen is used by aquatic ecosystem Katoogo and Bukuku springs in Kampala and its to produce carbon dioxide responsible for total environs. Further, Lukubye and Andama [19] alkalinity.

reported electrical conductivities higher than $1000 \mu \mathrm{S} / \mathrm{cm}$ in some springs in Mbarara Municipality, Uganda. Higher conductivities are usually associated with high TDS and may be influenced by high temperatures that increase the mobility of ions in water.

\section{Total alkalinity}

Alkalinity is the capability of water to neutralize the acid [45]. Living organisms especially aquatic life, function best in a $\mathrm{pH}$ range of 6.0 to 9.0. Alkalinity is a measure of how much acid can be added in a liquid without causing a large change in $\mathrm{pH}$. The dissolved carbon dioxide from rain is the primary source of carbonate and bicarbonates ions in spring water. As it enters the soil or rocks, it dissolves more carbon dioxide in water. However, it is typically approximated by carbon dioxide, carbonic acid, bicarbonate and hydrogen ions. These species make up the carbonate system, one of the most important acid-base relationships in aquatic systems. In this study, there was no significant variation in concentration of total alkalinity $(\mathrm{p}=$ $0.732)$. Total alkalinity ranged between $120.01 \pm$ 0.68 to $165.16 \pm 33.56 \mathrm{mg} / \mathrm{L}$ for the water samples. The values of total alkalinity were below the maximum permissible level of 200 $\mathrm{mg} / \mathrm{L}$ [32]. There was a significant positive correlation difference of total alkalinity with DO

\section{Total hardness}

In ground water, hardness is mainly contributed by carbonates, bicarbonates, sulphates and chlorides of calcium and magnesium. Hardness is an indicator of the presence of calcium and magnesium in water. Hardness can be precipitated if the temperature rises. Total hardness results from the presence of covalent metallic cations of which calcium and magnesium are the most predominant in ground water $[46,47]$. Calcium ions are common in water sources, which are probably triggered by leaching of the rocks [48]. The acceptable limit of total hardness is $300 \mathrm{mg} / \mathrm{L}$ whereas the maximum limit is $600 \mathrm{mg} / \mathrm{L}$. The hardness of the analyzed water samples varied from $33.66 \pm 2.08$ to $71.20 \pm 2.85 \mathrm{mg} / \mathrm{L}$. The mean total hardness for all springs were below the WHO (2017a) recommended range of $100-300 \mathrm{mg} / \mathrm{L}$ hence the water is not hard and is suitable for drinking and for other domestic uses. Total hardness showed significant difference between the springs and tap water $(\mathrm{p}<0.05)$. The springs had higher hardness than tap water, corroborating a previous report in Mbarara district [19]. This may be because January is a dry period in which evaporation of water led to increase in concentration of calcium and magnesium (total hardness). 


\section{Calcium and magnesium}

Calcium concentration ranged between $10.08 \mathrm{mg} / \mathrm{L}$ and $16.47 \mathrm{mg} / \mathrm{L}$. The element calcium is the most important and abundant in the human body and adequate intake is essential for normal growth and health. Magnesium concentration ranged between $20.17 \mathrm{mg} / \mathrm{L}$ and $60.54 \mathrm{mg} / \mathrm{L}$. Magnesium concentration in spring $\mathrm{C}$ was the highest, which could be attributed to mineralization processes of carbonate-containing rock materials in contact with water such as dolomite and calcite. In addition to that, evaporation of water occurred that led to increase in concentration of calcium and magnesium. Magnesium is abundant and a major dietary requirement for human (0.3-0.5 g/day). It is the second major constituent of hardness and it generally comprises $15-20 \%$ of the total hardness. All the recorded concentrations of calcium and magnesium were found to be below the prescribed ranges of $50-75 \mathrm{mg} / \mathrm{L}$ and $30-50$ $\mathrm{mg} / \mathrm{L}$ respectively [32].

\section{Fluorides}

Fluoride is a naturally occurring compound derived from fluorine, the thirteenth most abundant element on the earth's crust. High fluoride concentration in water reflects the solubility of calcium fluoride, associated with soft, alkaline and calcium deficient waters. Fluoride compounds occurring in drinking water in the absence of calcium are mostly bioavailable and are well absorbed in the gastrointestinal tract.
Consequently, drinking water is a potential source of fluoride that can lead to fluorosis which affects the teeth (dental fluorosis) and the bones when the concentration reaches $1.5 \mathrm{mg} / \mathrm{L}$ [49]. In this study, fluoride concentrations varied from $0.11 \pm 0.01$ to $2.45 \pm 0.10 \mathrm{mg} / \mathrm{L}$. There was significant variation in fluoride concentration among the water samples ( $\mathrm{p}<0.05)$, with springs $\mathrm{B}$ and $\mathrm{C}$ having higher concentrations than springs $A$ and $D$. This is attributable to geogenic processes such as dissolution of various minerals present in rocks and soils. All the spring water samples had fluorides in concentrations above the minimum limit of $1.5 \mathrm{mg} / \mathrm{L}$ recommended by [32], and this could be due to the presence of fluoride-containing compounds in Kisoro volcanic area. Therefore, water from these springs is not suitable for drinking.

\section{Chlorides}

Chlorides are common constituents of allnatural waters. Higher values of it impart a salty taste to water making it unacceptable for human consumption. This could be attributed to dissolution of salt deposits, domestic and industrial sewage discharge of effluents. Chloride content of the water samples varied between $20.35 \pm 1.37$ and $30.04 \pm 6.65 \mathrm{mg} / \mathrm{L}$, with no significant variations observed between the water samples $(p=0.288)$. The values were comparable to 6.0 to $79.0 \mathrm{mg} / \mathrm{L}$ in Kasenyi and Katwe springs [20] and 2.62 to $73.50 \mathrm{mg} / \mathrm{L}$ reported in Katoogo, Katalina and Bukuuku 
springs in Kampala [14]. Tap water showed a relatively higher concentration of chlorides than other samples, and this is explained by the addition of chlorine during tap water treatment before it is distributed to the public. All the chloride concentrations recorded were however below the prescribed limit of $250 \mathrm{mg} / \mathrm{L}$ by WHO [32].

\section{Phosphates}

The amount of phosphates is a vital water quality parameter because phosphates are considered to be the primary drivers of eutrophication in aquatic ecosystems [50]. Phosphates enter waterways from human and animal wastes, phosphorus-rich bedrock, laundry, cleaning, industrial effluents and phosphate-fertilizer runoffs. Phosphates become detrimental when they over fertilize aquatic plant and cause step up eutrophication [51]. Algae exploit mineral phosphorus either by altering various organic phosphates or in the form of orthophosphates by absorbing it immediately. Enzymes called alkaline and acid phosphatases are grown by algae to hydrolyze organic phosphates and remove assimilable mineral orthophosphate. Analysis of water samples in this study showed that the concentration of phosphates in Chuho spring and tap water ranged from 0.17 to $0.89 \mathrm{mg} / \mathrm{L}$ which were within the prescribed WHO limit of $5.0 \mathrm{mg} / \mathrm{L}$ [32]. Temperature and $\mathrm{pH}$ are considered to be the factors that lead to low phosphate concentration. Increase in $\mathrm{pH}$ decreases phosphate concentration. According to Pearson's correlation, phosphates had a negative correlation with temperature and $\mathrm{pH}(r=-0.019$, $\mathrm{p}=0.919 ; r=-0.327, \mathrm{p}=0.078)$.

\section{Copper}

The concentration of copper in the water samples in the study ranged from $0.72 \pm 0.40$ $\mu \mathrm{g} / \mathrm{L}$ (in spring D) to $11.72 \pm 1.11 \mu \mathrm{g} / \mathrm{L}$ (tap water). None of the sampled Chuho water springs or tap water samples had copper in concentrations above the maximum limit of 2000 $\mu \mathrm{g} / \mathrm{L}$ by WHO [32]. Such low copper concentrations were previously reported for water samples from Katoogo, Katalina and Bukuuku springs in Kampala [14]. It was observed that copper concentration in the water samples were generally low. However, tap water samples showed the highest concentration of copper. This could have been due to agricultural chemicals of copper compounds at the source or from corrosion of copper into water in the pipe system. Copper intake at high concentrations results into copper poisoning characterized by vomiting (usually hematemesis) and gastrointestinal distress [52].

\section{Iron}

Iron is an essential trace metal present in rocks but also found in water with no set regulatory level in drinking water [32, 53]. However, it is usually found at concentrations of 0.5 to $50 \mathrm{mg} / \mathrm{L}$ in natural fresh water [54]. The maximum iron concentration was $0.09 \pm 0.02$ $\mathrm{mg} / \mathrm{L}$ (for water from spring $\mathrm{C}$ ) and a minimum 
concentration of $0.03 \pm 0.01 \mathrm{mg} / \mathrm{L}$ for Spring D and tap water. Similar lower iron concentrations of $0.00853 \mathrm{mg} / \mathrm{L}$ to $0.0173 \mathrm{mg} / \mathrm{L}$ were reported for water samples drawn from Katoogo, Katalina and Bukuuku springs in Kampala [14]. Overall, the concentration of iron recorded in the water samples did not vary significantly $(p=0.780)$. The higher concentration of iron observed for water from spring $B$ could be due to the geological composition of rocks and soil structure, and the depth of the aquifer of an area are known to influence its ground water iron levels $[55,56]$. Though not usually of much concern, excessive dissolved ferrous iron gives water a disagreeable metallic taste, and promotes undesirable growth of "iron bacteria". In addition, high iron content can damage the liver, pancreas and heart or cause diabetes, hemochromatosis, stomach problems, nausea, and vomiting [57].

\section{Arsenic}

For all the spring water and tap water samples, the concentration of arsenic obtained were below the method detection limit of 0.00 $\mu \mathrm{g} / \mathrm{L}$ (Table 1). Arsenic along with lead, mercury and cadmium are listed in the WHO's list of topten chemicals of major public concern in water due to their high toxicity, persistence in the environment and bioaccumulative nature [58]. Arsenic is naturally present at high concentrations in groundwater, and chronic exposure to inorganic arsenic through drinking- water is reported to be immunotoxic, aggravate the risks of skin, lungs, bladder and kidney cancer and other dermal changes such as hyperkeratosis and pigmentation changes. It is also associated with cardiovascular diseases and diabetes whereas in utero and early childhood exposure leads to reduced cognitive development and increased risks of acute respiratory infections deaths in infants [59-61].

Water Quality Index of the springs and tap

The WQI is used to interpret complex analytical data obtained from water analysis into a water quality information that is easily understood by decision makers and the general public [62]. The WQI expresses the overall quality of any water sample under investigation so that the water status can be known (for instance fit for drinking or unfit). The CCMEWQI value enables the water to be ranked as poor (0-44), marginal (45-64), fair (65-79), good (80$89)$, very good (90-94) and excellent (95-100) [33]. The WQI index obtained in this study (Table 2) shows that the water quality of springs $\mathrm{A}, \mathrm{B}$ and $\mathrm{C}$ are marginal while water of springs D and tap water are fair and good, respectively.

Table 2. CCME-WQI values for Chuho springs and tap water

\begin{tabular}{|l|c|c|c|c|c|}
\hline $\begin{array}{l}\text { Sampling } \\
\text { point }\end{array}$ & F1 & F2 & F3 & $\begin{array}{c}\text { CCME- } \\
\text { WQI }\end{array}$ & Rank \\
\hline Spring A & 31.25 & 31.25 & 52.83 & 60.23 & Marginal \\
\hline Spring B & 31.25 & 31.25 & 55.27 & 59.14 & Marginal \\
\hline Spring C & 31.25 & 31.25 & 56.59 & 58.54 & Marginal \\
\hline Spring D & 25.00 & 25.00 & 48.39 & 65.39 & Fair \\
\hline Tap water & 18.75 & 18.75 & 15.53 & 82.26 & Good \\
\hline
\end{tabular}


The water quality of springs $\mathrm{A}, \mathrm{B}$ and $\mathrm{C}$ is frequently threatened and the conditions depart from the natural or desirable levels. Water quality of spring $\mathrm{D}$ is protected but occasionally threatened. Water quality of the tap water is protected with only a minor degree of threat, conditions rarely depart from desirable levels. However, the WQI results revealed acceptable levels of the water quality (marginal to good) for the Chuho springs studied.

\section{Conclusions}

Some of the physical and chemical parameters of water samples taken from Chuho springs and the tap were found to be outside the recommended guidelines for drinking water by the WHO. Temperature, dissolved oxygen and fluorides were outside the recommended limits of $15^{\circ} \mathrm{C}, 10-12 \mathrm{mg} / \mathrm{L}$ and $1.5 \mathrm{mg} / \mathrm{L}$, respectively. Further research should be done to investigate other potential water contaminants of microbial and radioactive origin, along with sanitary assessment of the springs. The variations of the physicochemical parameters should be investigated during the wet season. Modeling and predicting water quality using artificial intelligence should be applied in the Chuho springs so as to improve the monitoring of its water quality.

\section{Acknowledgement}

The authors are grateful to Mbarara University of Science and Technology for the support and the technical assistance rendered which made this research a success.

\section{References}

[1] Treacy J. Drinking Water Treatment and Challenges in Developing Countries. In: The Relevance of Hygiene to Health in Developing Countries, IntechOpen, pp. 1-23. 2019.

[2] Beshearse E, Bruce BB, Nane GF, Cooke RM, Aspinall W, Hald T, et al. Attribution of Illnesses Transmitted by Food and Water to Comprehensive Transmission Pathways Using Structured Expert Judgment, United States. Emerg Infect Dis. 2021; 27: 182-195.

[3] The United Nations. 2019. The United Nations World Water Development Report 2019. Leaving no one behind.

https://unesdoc.unesco.org/ark:/48223/pf0000367276.loca le $=$ en.

[4] Mutono N, Wright J, Mutembei H, Muema J, Mair T, Mutunga M, Thumbi S. The nexus between improved water supply and water-borne diseases in urban areas in Africa: a scoping review protocol. AAS Open Res. 2020; $3: 12$.

[5] Ngowi HA. Prevalence and pattern of waterborne parasitic infections in Eastern Africa: A systematic scoping review. Food Waterborne Parasitol. 2020; 20: e00089.

[6] WHO, Drinking-water. 2019.

https:/www.who.int/news-room/factsheets/detail/drinking-water.

[7] Mari L, Casagrandi R, Bertuzzo E, Rinaldo A, Gatto M. Conditions for transient epidemics of waterborne disease in spatially explicit systems. Royal Soc Open Sci. 2019; 6: 181517.

[8] Ntajal J, Falkenberg T, Kistemann T, Evers M. Influences of Land-Use Dynamics and Surface Water Systems Interactions on Water-Related Infectious Diseases-A Systematic Review. Water. 2020; 12: 631.

[9] BORGEN Magazine. 2020. Poor Sanitation in Kenya Leads to Water-Borne Diseases. https://www.borgenmagazine.com/sanitation-in-kenya-2/. 
[10] Marks SJ, Clair-Caliot G, Taing L, Bamwenda JT, Kanyesigye C, Rwendeire NE, Kemerink-Seyoum JS, Kansiime F, Batega DW, Ferrero G. Water supply and sanitation services in small towns in rural-urban transition zones: The case of Bushenyi-Ishaka Municipality, Uganda. npj Clean Water. 2020; 3: 21.

[11] Huston A, Gaskin S, Moriarty P, Martin W. More sustainable systems through consolidation? The changing landscape of rural drinking water service delivery in Uganda. Water Alternat. 2021; 14: 248-270.

[12] Lifewater International. 2020. The Uganda Water Crisis: Facts, Progress, and How to Help. https://lifewater.org/blog/uganda-water-crisis/.

[13] Businge F, Kagoya S, Omara T, Angiro C. Pollution of Mpanga River by Kabundaire Abattoir Effluents, Fort Portal Tourism City, Uganda. Asian J Fish Aquat Res. 2021; 11: 34-43.

[14] Moulodi S, Thorsell J. Evaluation of the Levels of Selected Trace Metal Pollutants in Groundwater and Soil from Protected Springs in Peri-Urban Kampala, Uganda. Masters Dissertation. TRITA-LWR Degree Project 13: 17. Royal Institute of Technology (KTH). 2013: 1-56.

[15] Omara T, Nassazi W, Adokorach M, Kagoya S. Physicochemical and microbiological quality of springs in Kyambogo university propinquity. OALib J. 2019;6:1-13.

[16] Agensi A, Tibyangye J, Tamale A, Agwu E, Amongi C. Contamination Potentials of Household Water Handling and Storage Practices in Kirundo Subcounty, Kisoro District, Uganda. J Environ Public Health. 2019; 2019: 7932193.

[17] Ojok W, Wasswa J, Ntambi E. Assessment of seasonal variation in water quality in River Rwizi using multivariate statistical techniques, Mbarara municipality, Uganda. J Water Res Protect. 2017; 9:83-97.

[18] Omara T, Karungi S, Kalukusu R, Nakabuye BV, Kagoya S, Musau B. Mercuric pollution of surface water, superficial sediments, Nile Tilapia (Oreochromis nilotica Linnaeus 1758 [Cichlidae]) and yams (Dioscorea alata) in auriferous areas of Namukombe stream, Syanyonja, Busia, Uganda. PeerJ. 2019;7: e7919.
[19] Lukubye B, Andama M. Physico-chemical quality of selected drinking water sources in Mbarara Municipality Uganda. J Water Res Protect. 2017; 9:707-722.

[20] Haruna R, Ejobi F, Kabagambe EK. The quality of water from protected springs in Katwe and Kisenyi parishes, Kampala city, Uganda. Afr Health Sci. 2005;5:14-20.

[21] Egor M, Mbabazi J, Ntale M. Heavy Metal and Nutrient Loading of River Rwizi by Effluents from Mbarara Municipality. J Chem Mat Res. 2014; 2: 36-47.

[22] Bwire G, Sack DA, Kagirita A, Obala T, Debes AK, Ram M, Komakech H, George CM, Orach CG. The quality of drinking and domestic water from the surface water sources (lakes, rivers, irrigation canals and ponds) and springs in cholera prone communities of Uganda: an analysis of vital physicochemical parameters. BMC Public Health. 2020; 20: 1128.

[23] Twinamatsiko M, Ayebare S, Mabirizi D, Kasangaki A, Babaasa D. A Survey of Hydrological Systems in the Great Virunga Landscape: Water resources assessment and use in and around Mgahinga Gorilla National Park and Echuya Central Forest Reserve, South Western Uganda. Institute of Tropical Forest Conservation, Mbarara University of Science and Technology. 2015.

[24] Sengalama T, Quillérou E. Paying for Water in Uganda: Is Paying Upstream Land Users a Possible Solution? Solutions. 2016: 64-73.

[25] Sustainable Sanitation Alliance, Compilation of 25 case studies on sustainable sanitation projects from Africa. 2012.

[26] NEMA. The state of environment report for kisoro district 2007/2008 kisoro district local government. Psychology Curricular Materials. Book 1. 2007.

[27] Directorate of Water Development, Ministry of Water and Environment, Republic of Uganda, Kisoro District - Uganda Water Supply Atlas. 2017.

[28] Uganda Bureau of Statistics. 2018. Population of Kisoro District in 2014. 
https://www.citypopulation.de/php/uganda-

admin.php?adm2id=018.

[29] Tindimugaya C, Gaye CB. Use of isotopes in the management of Kisoro town water supply, Uganda. International symposium on isotope hydrology and integrated water resources management, Vienna (Austria), 19-23 May 2003. https://wwwpub.iaea.org/MTCD/Meetings/PDFplus/cn104synb.pdf. [30] Angiro C, Abila PP, Omara T. Effects of industrial effluents on the quality of water in Namanve stream, Kampala Industrial and Business Park, Uganda. BMC Res Notes. 2020; 13:220.

[31] American Public Health Association (APHA). Standard methods for examination of water and wastewater, vol. 20. Washington: American Public Health Association; 1995.

[32] WHO. Guidelines for drinking-water quality, 4th edition, incorporating the 1st addendum. World Health Organization. 2017.

[33] Khan H, Khan AA, Hall S. The Canadian water quality index: a tool for water resources management. MTERM International Conference, 06 - 10 June 2005 AIT, Thailand, 2005.

[34] Olajire AA, Imeokparia FE. Water Quality Assessment of Osun River: Studies on Inorganic Nutrients. Environ Monit Assess. 2001; 69:17-22.

[35] Palamuleni L, Akoth M. Physico-Chemical and Microbial Analysis of Selected Borehole Water in Mahikeng, South Africa. J Environ Res Public Health. 2015; 12: 8619-8630.

[36] Okot J, Otim J. The quality of drinking water used by the communities in some regions of Uganda. Int J Biol Chem Sci. 2015; 9:552-562.

[37] WHO, Guidelines for Drinking-Water Quality: Fourth Edition Incorporating the First Addendum. Geneva: World Health Organization: Acceptability aspects: Taste, $\begin{array}{lll}\text { odour and } & \text { appearance. }\end{array}$ https://www.ncbi.nlm.nih.gov/books/NBK442378.

[38] Clean Water Team. State Water Resources Control Board Color of Water Fact Sheet 3.1.5.9. 2005. https://www.waterboards.ca.gov/water_issues/programs/s wamp/docs/cwt/guidance/3159.pdf.

[39] Nshekanabo N, Wozei E. Spring Water Quality Improvement in Slums. Sanitation and Water for All. Proceedings of 24th WEDC Conference, Islamabad. 1997, p. 264-266.

[40] Byamukama D, Kansime F, Mach IR, Farnleitner A. Determination of Escherichiacoli Contamination with Chromocult Coliform Agar Showed a High Level of Discrimination Efficiency for Differing Pollution Levels in Tropical Waters of Kampala, Uganda. Appl Environ Microbiol. 1999;66: 864-868.

[41] Omara T, Nteziyaremye P, Akaganyira S, Opio DW, Karanja LN, Nyangena DM, et al. Physicochemical quality of water and health risks associated with consumption of African lung fish (Protopterus annectens) from Nyabarongo and Nyabugogo rivers, Rwanda. BMC Res Notes. 2020;13:66.

[42] WHO. World Health Organisation Guidelines for Drinking Water. World Health Organisation Press, Geneva. 1996.

[43] Fraser LH, Keddy PA. The World's Largest Wetlands: Ecology and Conservation. University Press, Cambridge. 2005.

[44] Yasin M, Ketema T, Bacha K. Physico-chemical and bacteriological quality of drinking water of different sources, Jimma Zone, Southwest Ethiopia. BMC Res Notes. 2015; 8: 541.

[45] Rahmanian N, Siti HBA, Homayoonfard M, Ali NJ, Rehan M, Sadef Y, Nizami AS. Analysis of physiochemical parameters to evaluate the drinking water quality in the state of Perak, Malaysia. J Chem. 2015; 2015: 716125.

[46] Tyson A, Harrison K. Water Quality for Private Water Systems. University of Georgia, Athens, Georgia. 1990.

[47] Patil SG, Chonde SG, Jadhav AS, Raut PD. Impact of Physico-Chemical Characteristics of Shivaji University Lakes on Phytoplankton Communities, Kolhapur, India. Res J Recent Sci. 2012; 1: 56-60. 
[48] Agunwamba JC. Water Engineering Systems. 2nd Edition, Immaculate Publications Limited, Enugu. 2000.

[49] DenBesten P, Li W. Chronic fluoride toxicity: dental fluorosis. Monograph Oral Sci. 2011; 22: 81-96.

[50] Li T, Chu C, Zhang Y, Ju M, Wang Y. Contrasting eutrophication risks and countermeasures in different water bodies: Assessments to support targeted watershed management. Int J Environ Res Public Health. 2017; 14: 695 .

[51] Liu X, Zhang G, Sun G, Wu Y, Chen, Y. Assessment of lake water quality and eutrophication risk in an agricultural irrigation area: A case study of the Chagan Lake in Northeast China. Water. 2019; 11: 2380.

[52] Arvind K. Ecobiology of Polluted Waters. Daya Publishing House, India. 2007: p. 1-291.

[53] Frisbie SH, Mitchell EJ, Dustin H, Maynard DM, Sarkar B. World Health Organization discontinues its drinking-water guideline for manganese. Environ Health Perspect. 2012; 120: 775-778.

[54] WHO. Guidelines for drinking-water quality, Third edition, incorporating first addendum (third edition). World Health Organization. 2004. http://www.who.int/water_sanitation_health.

[55] Nhapi I, Wali UG, Uwonkunda BK, Nsengimana H, Banadda N, Kimwaga R. Assessment of water pollution levels in the Nyabugogo catchment, Rwanda. Open Environ Eng J. 2011;4:40-53.

[56] Nteziyaremye P, Omara T. Bioaccumulation of priority trace metals in edible muscles of West African lungfish (Protopterus annectens Owen, 1839) from Nyabarongo River, Rwanda. Cogent Environ Sci. 2020; 6: 1779557.

[57] WHO. Iron in drinking-water. Background document for development of WHO Guidelines for Drinking-water $\quad 2003$. https://www.who.int/water_sanitation_health/dwq/chemic als/iron.pdf.

[58] WHO. Ten chemicals of major public health concern.

2019 http://www.who.int/ipcs/assessment/public_health/chemic als_phc/en/.

[59] Fazan SF, Karagas MR, Chen Y. In utero and early life arsenic exposure in relation to long-term health and disease. Toxicol Appl Pharmacol. 2013; 272: 384-90. [60] Ahmed SM, Branscum A, Welch BM, Megowan M, Bethel JW, Odden MC, et al. A prospective cohort study of in utero and early childhood arsenic exposure and infectious disease in 4- to 5-year-old Bangladeshi children. Environ Epidemiol. 2020; 4: e086.

[61] Navasumrit P, Chaisatra K, Promvijit J, Parnlob V, Waraprasit S, Chompoobut C, et al. Exposure to arsenic in utero is associated with various types of DNA damage and micronuclei in newborns: a birth cohort study. Environ Health. 2019; 18: 51.

[62] Calmuc M, Calmuc V, Arseni M, Topa C, Timofti M, Georgescu LP, Iticescu C. A comparative approach to a series of physico-chemical quality indices used in assessing water quality in the Lower Danube. Water. 2020; 12: 3239 . 